\title{
Collective decision-making with 4D BIM: Collaboration group persona study
}

\author{
Veronika Bolshakova $^{1,2}$, Annie Guerriero ${ }^{3}$, Hugo Carvalho ${ }^{4}$, Gilles Halin ${ }^{1,5}$ \\ ${ }^{1}$ UMR n`3495 Modèles et simulations pour l'Architecture et le Patrimoine Centre de \\ Recherche en Architecture et Ingénierie - MAP-CRAI, ENSAN, Nancy 54000, France \\ ${ }^{2}$ Centre National de la Recherche scientifique - CNRS, Paris 75794, France \\ ${ }^{3}$ Luxembourg Institute of Science and Technology - LIST, Esch-sur-Alzette, Luxembourg \\ ${ }^{4}$ Psychologie Ergonomique et Sociale pour l'Expérience utilisateurs EA7312 -
} PErSEUs, UL, Metz, France

${ }^{5}$ Université de Lorraine - UL, Nancy 54000, France

bolshakova@erai.archi.fr

\begin{abstract}
D BIM assures more detailed costs and error control, whilst also improving scheduling and coordination. It relies on interoperability and high levels of collaboration, which have increased the value of collective competencies. In addition to the competencies, the collaboration group internal influences and subordination must be considered as well. While the knowledge and competencies of each and every individual team member are important, BIM allows the team to use the entire set of collective knowledge, skills and competencies, which are the key feature for advanced digital management of the AEC project. Such management requires a successful implementation and efficient use of 4D or nD BIM. This study proposes to summarize collaboration personae of AEC project collaborative groups, and to associate the collective knowledge and competencies to 4D BIM uses. Further, it will be completed with interviews on current $4 \mathrm{D}$ practices with BIM professionals. Moreover, through this research, we continue to progress towards a new 4D collective decision-making support proposition.
\end{abstract}

Keywords: 4D BIM, 4D BIM uses, Decision-making, Digital collaboration, Collaboration persona, Collaboration group, Collective decision support.

\section{Introduction}

AEC industry transformation, influenced by the latest information and communication technologies, is due to a major shift of this economic sector towards the new digital globalized economy [1]. The changes brought in the last decades by digital tools and by the progressive adoption of Building Information Modeling/Management (BIM) have had an impact on the common practices of design, management and construction of projects, and subsequently, have brought in new business models [2]. The advanced digital project management is one of the key features for an effective BIM project management [3]. Over the project development, collective competencies are 
implemented into both the project design development and value engineering processes [4]. In the literature and in practice 4D BIM is mostly used as a process visualization support [5], whereas we focus on 4D BIM uses for decision-making [6].

Decision-making sessions unite the stakeholders' competencies to benefit from better communication and from collective intelligence as a decision assistance tools. But how does a group organize decision-making? Which competencies are required to efficiently support 4D? How should the collaboration persona adjust to 4D BIM uses?

Firstly, this paper introduces collaboration and decision-making in the scope of the $\mathrm{BIM}$ era, in order to understand collaboration types and their place in the project workflow. The next part introduces 4D BIM uses, and proposes a collaboration personae summary study. The final part describes a methodology of future research.

\section{4D collective decision-making support development steps}

4D BIM offers more detailed cost and error control, whilst also improving scheduling and coordination. It relies on interoperability and high levels of collaboration, which have increased the value of collective competencies. Thus it is important to understand which competences are relevant for which decisions, and how should the collective decision-making be organized in correlation with project phases, scale, contracts, etc.

\subsection{D Collab project research stages}

This paper is a part of research conducted for the 4D Collab (http://www.4dcollabproject.eu) international project which aims to develop a proposition of decisionmaking support configuration and collaboration scenarios for 4D BIM. Fig. 1 shows the research stages, where firstly, a series of experiments with existing digital synchronous collaboration tools ("Shariiing" software https://www.shariiing.com by Immersion and multi-touch screens table and wall) have already been conducted.

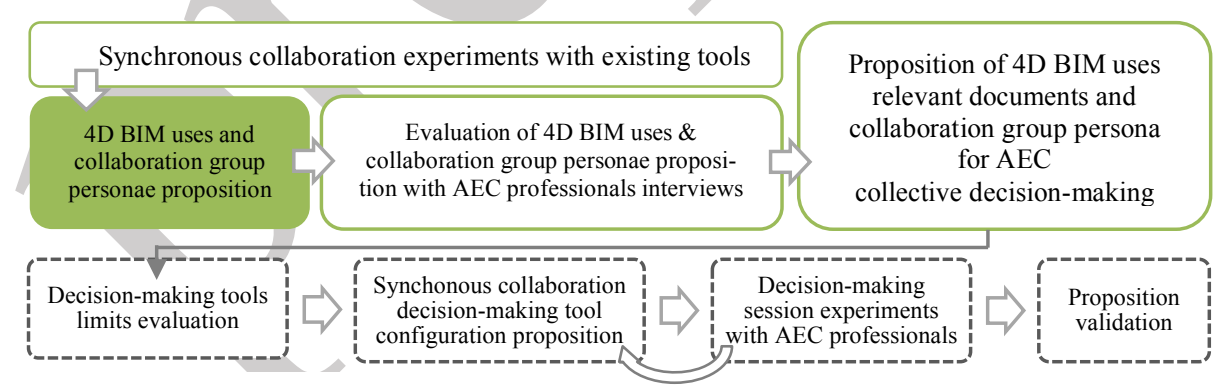

Fig. 1. Summary of methodology steps for decision-making support proposition

The experiment scenario required AEC professionals to collaborate and to resolve some design development and value engineering tasks with the assistance of 3D models, and it summarizes the limits of present collaboration solutions and the users demand for more natural and AEC customized interactions [7]. As the next stage, this paper summarizes collaboration groups and also personae study and 4D BIM uses, 
which will be evaluated and improved with the further research (4.4). Subsequently, a decision-making tools evaluation and specification will complete the tool proposition. Finally, AEC professionals decision-making sessions with the use of $4 \mathrm{D}$, a touch table and Shariiing software, altered to 4D interactions, conclude the research.

\subsection{Digital interactive interfaces for 4D BIM collaborative context}

Digital project development and management rely on specific technical tools, with BIM the tools are in the core of a sociotechnical system, and they are operated by social elements: synchronous collaboration, coordinated work practices, institutional and cultural frameworks [8] [9]. Various systems provide users with necessary options and interactions. Yet, there is a gap in solutions for synchronous co-located collaboration and decision-making. Thus, we propose to develop a multi-user digital documents interaction interface, which will complete a digital continuity of project documents at decision-making sessions, with an aim to avoid printing documents and primarily to keep the same BIM model in the center of discussions as in the center of design development. The solution aims to avoid incorrect interpretation and losses of information. For users' comfort it is important to offer the best usability and relevant interactions.

Natural user interfaces (NUI) offer the ease of access and low appropriation time with a tool [10], therefore we propose to implement a multi-touch collaborative table and wall within a NUI as a technical support for decision-making. The interface fosters 4D BIM uses with project documents convergence with the ease of interactions.

\section{AEC project collaboration, decision-making and 4D BIM uses}

Any project development includes decision-making activities, with a collaborative BIM model and a range of project participants' competencies (e.g. knowledge, skills, experience) assisting decision-making. This part introduces AEC decision-making essentials with an objective to outline potential 4D BIM collaboration process requirements.

\subsection{AEC project collaboration}

AEC projects are highly dependent on local conditions, they usually involve stakeholders who have not been working together before [11]. The project team is almost always temporary, and has specific tasks and responsibilities [12], these factors do not foster stakeholders to integrate completely into the BIM collaboration process and network.

Naturally, different ways of working together are implied in project development, with networking at a basic level, followed by coordination, then cooperation and the highest level is collaboration, where actors have information exchanges, alternate activities, share resources and have a mutual benefit (collaborative continuum) [13]. In addition, "the integration" is a concept where the parts are no longer apparent. A custom collaborative BIM decision framework implementation, suggested by $\mathrm{Gu}$ and 
London [14], offers to provide the actors with the understanding and implementations of BIM technologies. Even if BIM relies on technology, as a core of BIM sociotechnical system, collaboration still stays a human activity. Collaboration can be synchronous or asynchronous, collocated or distant. Collocated synchronous project sessions are the main subject of our study on collective decision-making with 4D.

\subsection{AEC project decision-making}

According to Hughes and Murdoch, an AEC project starts and ends with decision points, the decision classes are: Policy, Strategic, Tactical and Operational [15]. Also any project requires various types of decision roles systems summarized in Table 1, where three systems have various action types involved. Depending on project lifecycle, and on decision types there will be relevant decision-making constitutes involved.

Table 1. Decision roles systems (by Hughes and Murdoch [15])

\begin{tabular}{lll}
\hline Operating & Control & Managing \\
\hline Operating & Monitoring & Coordinating \\
Cooperating & Supervising & Directing \\
Advising & Resourcing & Recommending \\
Receiving & & Approving \\
\hline
\end{tabular}

\subsection{AEC project lifecycle and 4D BIM uses}

The first concepts of time management are usually introduced even earlier than the design development starts, and with the design progress the time management evolves from a simple programming, to a planning and then to a detailed scheduling [16]. This evolution also involves the BIM model development with an increase of level of detail (LOD) (Fig.2). The phase of Operation \& Maintenance does not enter into the scope of current study due to the specifics and phases' relevance mostly to activity management.

\begin{tabular}{|c|c|c|c|}
\hline $\begin{array}{ll}\text { Project } & \text { Pre-design } \\
\text { identification } & \text { Schematic design } \\
\text { Program Design development } & \text { Dem } \\
\text { BIM MODEL LOD }\end{array}$ & $\begin{array}{l}\text { Pre-construction } \\
\text { Construction } \\
\text { documentation }\end{array}$ & $\begin{array}{l}\text { Construction } \\
\text { Fabrication }\end{array}$ & $\begin{array}{l}\text { Operation \& } \\
\text { Maintenance }\end{array}$ \\
\hline $\begin{array}{l}\text { Conceptual Approximate } \\
\text { TIME MANAGEMENT }\end{array}$ & Precise & Detailed & Recorded \\
\hline \multirow[t]{5}{*}{$\begin{array}{ll}0 & \text { 4D Scheduling } \\
& \text { 4D Clash Detection }\end{array}$} & & & \\
\hline & \multicolumn{2}{|c|}{ 4D Safety Management } & \\
\hline & \multicolumn{2}{|c|}{ 4D Site Lay-out, Environment Management } & \\
\hline & \multicolumn{2}{|c|}{ 4D Constructability Management } & \\
\hline & & 4D Monitoring & \\
\hline
\end{tabular}

Fig. 2. Project phases and model LOD with 4D BIM use potential introduction 
When the "3D" dimension of the enriched virtual model of a project is completed with the notion of "Time", introduced as the "fourth dimension", the information from time management (time dimension \& related data) enriches the 3D Model (x,y,z geometry \& related spatial model elements data) and creates a 4D model with 4D relationships of attending data. Thus $4 \mathrm{D}$ is a model, but also a simulation, as "conceptually 4D CAD represents a type of graphic simulation of a process" [17]. One of 4D major benefits is information accessibility and clear visualization - all actors have access to a 3D model and an attached schedule, moreover they can access to simulations and analysis.

Kreider and Messner studied BIM uses and proposed a definition that: "BIM Use: A method or strategy of applying Building Information Modeling during a facility's lifecycle to achieve one or more specific objectives." [18]. Based on this uses study Guerriero et al. [6] summarized 4D BIM uses: 4D Scheduling, 4D Clash Detection, 4D Safety Management, 4D Site Lay-out \& Environment Management, 4D Constructability Management, 4D Monitoring and 4D Visual communication is core use. These uses can be introduced into the project on specific phases (Fig.2).

For example it is possible to forecast construction phases and sequencing as 4D Scheduling, once the first "3D" and "time" concepts are present, when the construction is started the scheduling is followed by $4 \mathrm{D}$ management, monitoring. All the uses involve stakeholders' expertise and collaboration. Digital documents, such as 4D BIM simulations, foster new collaborative project workflow implementation and develop new requirements for synchronous collaborative decision-making methods and supports (e.g. tools, documents, interactions).

\section{Designing a collective decision-making support for 4D BIM}

\subsection{AEC project collaboration groups and decision-making}

BIM engages the collective decision-making for design development or value engineering. The project stakeholders have many roles, influences \& interactions [19] (Responsible Validator, Responsible Coordinator, Participant Production, Participant Expert, Participant Reader [20]), but the current scope focuses on a group and not individuals.

Table 2 summarizes a proposition of main AEC project collaboration groups. The summary is general, it may vary from a project type, stakeholders contracts, etc. The groups are united by a General group's goal, which is related to a project development phase. The stakeholders collaborate on the project in various groups, carrying their project roles and bringing their expertise as a member of various groups in order to complete the goals. Group collaboration typology proposed by Mathews [21], summarizes the types and their descriptions (personnel, workstyle, leadership), thus in the table below Group collaboration style proposes to apply the types to AEC project teams.

The proposed summary (Table 2) suggests that collaboration type and decision class are related. Project development starts with a client-supplier collaboration type, engages a stable deliverable oriented professional design team with a democratic 
leadership to produce a design and then a democratic Committee with a BIM manager brings an order and control to the design collaboration. From a Pre-construction phase the project teams become more dynamic with a designated leader, also they continue the decision order from Management to Operation and then Control.

For example, on an early stage of project development a Project program team establishes the program and project requirements, approves design production, thus this group will have a collaboration type: client supplier, with the same core members of the team focusing on communication, with a designated leader. This group will make Policy class decisions, with a focus on management system roles, however other roles are possible as well, as the secondary ones. In addition, all the collaboration groups are the long life length groups, have an objective as a constant element and a motivation factor, except the BIM project team with the shared interest as a motivation. Also, most of the groups contain more than three members. However, for a BIM project team BIM is a core element, thus members receive guidance and coordination from BIM management. Moreover the teams must have technology and BIM basic skills and knowledge.

Table 2. Main characteristics, collaboration styles and decision-making classes study

\begin{tabular}{|c|c|c|c|c|c|c|c|c|}
\hline \multicolumn{3}{|c|}{ Phases: Program - Design } & \multicolumn{6}{|c|}{ Phases: Pre-construction - Construction } \\
\hline \multicolumn{9}{|c|}{ Group main characteristics } \\
\hline \multicolumn{9}{|c|}{ Group Name } \\
\hline $\begin{array}{l}\text { Project } \\
\text { program } \\
\text { team }\end{array}$ & $\begin{array}{l}\text { Project } \\
\text { design } \\
\text { team }\end{array}$ & $\begin{array}{l}\text { Design } \\
\text { process } \\
\text { team }\end{array}$ & $\begin{array}{l}\text { Pre- } \\
\text { construc- } \\
\text { tion man- } \\
\text { agement } \\
\text { team }\end{array}$ & $\begin{array}{l}\text { Construc- } \\
\text { tion design } \\
\text { team }\end{array}$ & $\begin{array}{l}\text { Construc- } \\
\text { tion docu- } \\
\text { ment } \\
\text { manage- } \\
\text { ment team }\end{array}$ & $\begin{array}{l}\text { Construc- } \\
\text { tion team }\end{array}$ & $\begin{array}{l}\text { Construc- } \\
\text { tion pro- } \\
\text { cess } \\
\text { team }\end{array}$ & $\begin{array}{l}\text { Safety } \\
\text { manage- } \\
\text { ment team }\end{array}$ \\
\hline \multicolumn{9}{|c|}{ Group members roles } \\
\hline $\begin{array}{l}\text { Client } \\
\text { Architects } \\
\text { Engineers }\end{array}$ & $\begin{array}{l}\text { Architects } \\
\text { Engineers }\end{array}$ & $\begin{array}{l}\text { BIM } \\
\text { manager } \\
\text { Architects } \\
\text { Engineers }\end{array}$ & $\begin{array}{l}\text { Construc- } \\
\text { tion } \\
\text { manager } \\
\text { Architects } \\
\text { Engineers } \\
\text { Client }\end{array}$ & $\begin{array}{l}\text { Contractors } \\
\text { Architects } \\
\text { Engineers }\end{array}$ & $\begin{array}{l}\text { s BIM } \\
\text { manager } \\
\text { Contractors } \\
\text { Architects } \\
\text { Engineers }\end{array}$ & $\begin{array}{l}\text { Contractors } \\
\text { Subcon- } \\
\text { tractors }\end{array}$ & $\begin{array}{l}\text { Construc- } \\
\text { tion } \\
\text { manager } \\
\text { Contractors } \\
\text { Architects } \\
\text { Engineers } \\
\text { Client } \\
\end{array}$ & $\begin{array}{l}\text { Safety } \\
\text { manager } \\
\text { Construction } \\
\text { manager } \\
\text { Contractors } \\
\text { Architects } \\
\text { Engineers } \\
\text { Client } \\
\end{array}$ \\
\hline \multicolumn{9}{|c|}{ General goal } \\
\hline $\begin{array}{l}\text { Conceive } \\
\text { the project } \\
\text { program } \\
\text { and re- } \\
\text { quirements } \\
\text { approve } \\
\text { design } \\
\text { production }\end{array}$ & $\begin{array}{l}\text { Design th } \\
\text { project an } \\
\text { the pro- } \\
\text { ject's BIM } \\
\text { model }\end{array}$ & $\begin{array}{l}\text { Control } \\
\text { and man- } \\
\text { age the } \\
\text { project } \\
\text { design } \\
\text { collabora- } \\
\text { tion and } \\
\text { BIM mod- } \\
\text { els quality }\end{array}$ & $\begin{array}{l}\text { Prepare, } \\
\text { coordinate } \\
\text { and survey } \\
\text { the project } \\
\text { pre- } \\
\text { construc- } \\
\text { tion phase }\end{array}$ & $\begin{array}{l}\text { Design the } \\
\text { project } \\
\text { construc- } \\
\text { tion docu- } \\
\text { mentation }\end{array}$ & $\begin{array}{l}\text { Manage the } \\
\text { project } \\
\text { construc- } \\
\text { tion docu- } \\
\text { ments and } \\
\text { efficient } \\
\text { teams } \\
\text { collabora- } \\
\text { tion }\end{array}$ & $\begin{array}{l}\text { Construct } \\
\text { the quality } \\
\text { project by } \\
\text { the pro- } \\
\text { gram and } \\
\text { require- } \\
\text { ments }\end{array}$ & $\begin{array}{l}\text { Prepare, } \\
\text { coordinate } \\
\text { and survey } \\
\text { the project } \\
\text { construc- } \\
\text { tion phase }\end{array}$ & $\begin{array}{l}\text { Manage the } \\
\text { project } \\
\text { construc- } \\
\text { tion site } \\
\text { security } \\
\text { over the } \\
\text { construc- } \\
\text { tion pro- } \\
\text { cess }\end{array}$ \\
\hline \multicolumn{9}{|c|}{ Group collaboration style } \\
\hline \multicolumn{9}{|c|}{ Collaboration type } \\
\hline $\begin{array}{l}\text { Client- } \\
\text { supplier }\end{array}$ & $\begin{array}{l}\text { Stable } \\
\text { team }\end{array}$ & Committee & $\begin{array}{l}\text { Client- } \\
\text { supplier }\end{array}$ & $\begin{array}{l}\text { Dynamic } \\
\text { team }\end{array}$ & Committee & $\begin{array}{l}\text { Dynamic } \\
\text { team }\end{array}$ & $\begin{array}{l}\text { Dynamic } \\
\text { team }\end{array}$ & $\begin{array}{l}\text { Dynamic } \\
\text { team }\end{array}$ \\
\hline \multicolumn{9}{|c|}{ Personnel } \\
\hline Stable & Stable & Stable & Dynamic & Dynamic & Stable & Dynamic & Dynamic & Dynamic \\
\hline
\end{tabular}


Communica- Pooling \& Pooling \& Communica- Pooling \& Pooling \& Pooling \& Communica- Communication focused $\mathrm{Co}$-creation $\mathrm{Co}$-creation tion focused Co-creation $\mathrm{Co}$-creation $\mathrm{Co}$-creation tion focused tion focused Leadership

Designated Democratic Democratic Designated Designated Democratic Designated Designated Designated $\begin{array}{llllll}\text { leaders } & \text { leaders } & \text { leaders } & \text { leaders } & \text { leaders } & \text { leaders }\end{array}$

Group decision-making class

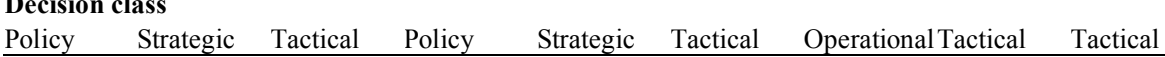

Decision system role: inside system role
Management: Operation: Control: $\quad$ Management: Operation: Control: Operation: Control: Control:

\begin{tabular}{lllll} 
Management: Operation: Control: & Management: Operation: Control: & Operation: Control: & Control: \\
Approving & Co-operating Supervising & Coordinating Co-operating Supervising & Co-operating Supervising & Supervising \\
\hline
\end{tabular}

\subsection{D BIM uses AEC project collaboration groups}

Collaboration groups may imply various 4D BIM uses according to the stage of progress of the project, as illustrated in Fig.1. Thus the proposed Project design team and Design process team on a design phase may use 4D Scheduling and Clash detection.

Further, these uses are required for Pre-construction management, Construction design and Construction document management teams, who also benefit from 4D Safety, Site lay-out, Environment, Constructability management. The groups encompass a large specter of 4D uses since the project model is well developed and there is a high concentration of management and coordination tasks on a pre-construction phase.

The Safety management team mostly benefits from 4D Safety management, however, keeps the connection with other $4 \mathrm{D}$ uses. For a Construction process team the 4D Monitoring and Construction management are the main uses. The Construction team may benefit from 4D Visualization for a better communication. The relevant uses for collaboration groups will be defined within the series of interviews (4.4) and 4D Collab research project experiments and survey results.

\subsection{Collaboration personas approach}

When project stakeholders collaborate in groups, the knowledge and competencies of every individual team member are important. Furthermore, BIM allows the team to use the entire set of collective knowledge, skills and competencies as parts of collective intelligence, which is the key feature for advanced digital management of the project.

In order to describe a project group collective activity, we propose to implement a collaboration persona (CP) approach [22], which is derived from the original user persona method, also called Individual Persona. CP describes a new type of persona which focuses on group goals and needs, instead of personal needs, and includes collaborative work aspects. According to Judge et al., "[c]ollaboration personae are empirically derived descriptions of hypothetical groups of people with specific qualities, goals and needs." [22]. In addition to the competencies, the collaboration group internal influences and subordination must be considered as well, because "[c]ollaboration personas include individual personas (playing the roles), who enact scenarios at different phases of the collaboration"[23]. In AEC project case the phases relate to development phases.

Matthews et al. [21] developed a CP based on collaboration types: dynamic project team, stable project team, customer-supplier relationship, committee, community and 
professional relationship. Every type is described with dimensions: goals (group tasks and motivation), group members (if the members are stable or dynamic), work style and leadership style (designated or democratic), etc. By the approach, CP are built from real work observations and guided interviews with a focus on group members (actors) experiences. CP aims to describe the needs and collaboration of group, interactions among actors and their goals. $\mathrm{CP}$ approach allows equipment designers to consider different actor roles throughout the collaboration process, and to be more focused on the group needs and interactions, in addition to the common user persona benefits [24].

\subsection{Design methodology of collaboration personae proposition}

This study suggests CP approach within an alteration to BIM specifics, and with a correlation to different problems encountered by the professionals' workgroups. Further research will run a series of BIM familiar professionals interviews, which will gather a real practices vision on the relevance of personae proposition and of specific $4 \mathrm{D}$ uses.

Methods: the non-directive interviews will gather personal experiences of participants about collaborative group work, and will focus on following themes: Who must be participating at the collaboration? Who participates on a collaboration in relevance to the project phase? Who participates in relevance to the 4D BIM use? Who is the role and responsibility of every member of the collaboration group and his contribution to the collective intelligence? How does a collaboration group organize decisionmaking? How are the collaboration sessions managed and held? Which information on the project was necessary for a decision-making and which competences? How does 4D BIM influence a decision-making at collaboration sessions?

The collected data will be studied with thematic analysis which is a qualitative method for analyzing and identifying themes or patterns [25]. The data sets gathered from the interviews will be classified, according to the research question, into the following themes: group and member goals; members and roles; group tasks; group work style; current 4D BIM collaboration tools and methods gaps. In addition, to test and to improve the $\mathrm{CP}$, we conduct a group interview with persona experienced designers.

Population: the interviews participants will be BIM experienced AEC project professionals: architects, structure, civic and MEP engineers, construction firms, construction managers, BIM mangers, safety, site and quantity managers and clients. The interviews provide a complementary information about the collaboration and project development process, also they will test our proposition relevance, additionally, they allow us to adjust the model of Matthews to the complex 4D BIM collaboration situations.

\subsection{D BIM uses and collaboration persona study}

With this research we continue to progress towards a new collective decision-making support proposition, which will be adapted to AEC specific needs and 4D BIM uses. Thus we need to study the support users and their needs. To study AEC collaboration 
groups we propose to apply the $\mathrm{CP}$ approach, since the single user persona description does not encompass collaborative aspects. The study proposition is based on common practices of project development and BIM implementation guides and protocols. The $\mathrm{CP}$ example for one of stakeholders group synopsizes main persona dimensions [21]: Context: a large public building project "A-project" is in development with BIM. Collaboration Persona Name: "A-project" Pre-construction management team. General goal: Prepare, coordinate and survey the project pre-construction phase. Roles: Client, Construction manager, Architects, Engineers (sometimes BIM manager, contractors, construction site, safety, quantities managers).

Project phase: Pre-construction, construction.

Workstyle: based on communication with a BIM model is in the core of collaboration, it evolves with the project, being more of a client-designers dialogue in the beginning, and changing to interdisciplinary collaboration.

Tasks: Identification of project limits; Establish the basis and progressive development of time management; Offer order to the project development process; Assure project deadlines and the basis for construction monitoring; etc.

Needs: strict aims and objectives of the program, an access to a digital workflow, work protocol, BIM methodology, technological core, interactions system, etc.

Skills and knowledge: related to roles, basic and advanced BIM and technology understanding, and collective intelligence and professional experience.

Dependences: Inside the group a Design team of architects and engineers supports the design basis of work and decision supports, and the construction manager is in strong dialogue with them, the client has a strong interaction with design team.

Decision-making: Policy and Strategic classes, focused on management: cooperating.

4D BIM place: 4D BIM model with a detailed schedule information, as a collaboration and decision-making support for 4D Scheduling, Clash Detection, Safety Management, Constructability Management, Site Lay-out \& Environment Management.

Every 4D BIM use requires specific decisions, in addition a relevant digital collaboration support for project documents must assist as a decision-making session equipment with relevant and easy interactions, and provide the digital documents continuum.

\section{Conclusion}

4D becomes a part of common practices for the professionals who have adopted high BIM and collaboration levels. Collaboration and precise project management are very important for the complex projects. The design, time, BIM process and construction managements play their role in development, and also require a collective decisionmaking, with collective skills and competences brought in by project stakeholders.

There are many collaboration groups on a construction project, and in correlation with the project goals we summarize general collaboration groups descriptions, identify their collaboration type and decision-making class. 
Groups are highly dependent on a project, however, with a collaboration persona approach for such a group description it is possible to design a new configuration for the methodology and equipment which will be relevant for a collaborative decisionmaking scenario on BIM projects, and for 4D BIM uses in particular. The new configuration aims to provide an efficient collocated synchronous digital collaboration and preserve the digital continuum. Thus, it is important to understand how the project groups collaborate and interact at decision-making to optimize the configuration.

Acknowledgments. The authors acknowledge financial support from Fonds Nationale de la Recherche (FNR) Luxembourg, and Agence Nationale de la Recherche (ANR) France, to 4DCollab grant reference: 11237662 (LU) / ANR-16- CE10-000601(FR).

\section{References}

1. Weippert, A., Kajewski, S.L.: AEC industry culture: a need for change. In: CIB World Building Congress 2004: Building for the Future. Toronto, Canada (2004).

2. Schultz, A., Essiet, M., Souza, D., Kapogiannis, G.: The Economics of BIM and added Value of BIM to Construction Sector and Society. Int. Counc. Res. Innov. Build. Constr. (2013).

3. Jadhav, S.: Application of Building Information Modeling in Construction Projects - A Critical Review. Int. J. Eng. Res. ISSN, 26-31 (2016).

4. Tory, M., Staub-French, S., Po, B.A., Wu, F.: Physical and digital artifact-mediated coordination in building design. Comput. Support. Coop. Work. 17, 311-351 (2008).

5. Boton, C., Kubicki, S., Halin, G.: Designing adapted visualization for collaborative 4D applications. Autom. Constr. 36, 152-167 (2013).

6. Guerriero, A., Kubicki, S., Berroir, F., Lemaire, C.: BIM-enhanced collaborative smart technologies for LEAN construction processes. 1063-1070 (2017).

7. Bolshakova, V., Halin, G., Humbert, P., Boton, C.: Digital Synchronous Collaboration Workspace and 3D Interactions for an AEC Project. Decision-Making Scenario Evaluation. CDVE 2017. 168-176 (2017).

8. Sackey, E.: A Sociotechnical Systems Analysis of Building Information Modelling (STSaBIM) Implementation in Construction Organisations. 12-22 (2014).

9. WPS Group \& Kaoris Future: Truths about BIM. (2018).

10. Steinberg, G.: Natural User Interfaces. Human-Computer Interact. INTERACT 2011.1 (2012).

11. McGraw Hill Construction: SmartMarket Report The business value of BIM for construction in major global markets: How Contractors Around the World Are Driving Innovation With Building Information Modeling. Bedford (2014).

12. Kubicki, S.: Assister la coordination flexible de l'activité de construction de bâtiments. Une approche par les modèles pour la proposition d'outils de visualisation du contexte de coopération. UL, Nancy, France (2006).

13. Himmelman, A.T.: Collaboration for a change. Fourth Int. Conf. Multi-Organizational Partnerships Coop. Strateg. Oxford Univ. England.(July 8-10). 11, 2004 (1997).

14. Gu, N., London, K.: Understanding and facilitating BIM adoption in the AEC industry. Autom. Constr. 19, 988-999 (2010).

15. Hughes, W., Murdoch, J.: Roles in Construction Projects: Analysis and Terminology. Construction Industry Publications, Birmingham (2001).

16. The Chartered Institute of Building: Guide to good practice in the managment of time in major projects. Dynamic time modelling. Wiley-Blackwell, Hoboken, HJ, USA (2018).

17. McKinney, K., Kim, J., Fischer, M., Howard, C.: Interactive 4D-CAD. Proc. third Congr. 
Comput. Civ. Eng. 135, 1261 (1996).

18. Kreider, R.G., Messner, J.I.: The Uses of BIM: Classifying and Selecting BIM Uses. The Pennsylvania State University, University Park, PA, USA (2013).

19. Halin, G., Hanser, D., Malcurat, O., Bignon, J.C.: A relational approach of cooperation in building design. 8th International Conference on Concurrent Enterprising.Rome,Italy (2002).

20. Bolshakova, V., Guerriero, A., Halin, G.: Identification of relevant project documents to 4D BIM uses for a synchronous collaborative decision support. In: Creative Construction Conference 2018. p. accepted for publication. Ljubljana, Slovenia (2018).

21. Matthews, T., Whittaker, S., Moran, T., Yuen, S.: Collaboration Personas: A New Approach to Designing Workplace Collaboration Tools. SIGCHI Conf. Hum. Factors Comput. Syst. 2247-2256 (2011).

22. Judge, T., Matthews, T., Whittaker, S.: Comparing collaboration and individual personas for the design and evaluation of collaboration software. Proc. 2012 ACM Annu. Conf. Hum. Factors Comput. Syst. - CHI '12. 1997 (2012).

23. Matthews, T., Whittaker, S., Moran, T., Yang, M.: Collaboration personas: A framework for understanding $\&$ designing collaborative workplace tools. Work. Collect. Intell. Organ. ACM CSCW. 582-595 (2010).

24. Bornet, C., Brangier, E.: The effects of personas on creative codesign of work equipment: an exploratory study in a real setting. CoDesign. 12, 243-256 (2015).

25. Braun, V., Clarke, V.: Using Thematic Analysis in Psychology. Qual. Res. Psychol. 3, 77101 (2006). 